\title{
A Comprehensive Analysis of E-government services adoption in Saudi Arabia: Obstacles and Challenges
}

\author{
Mohammed Alshehri, Steve Drew, Osama Alfarraj \\ School of ICT, Griffith University \\ Brisbane, Australia
}

\begin{abstract}
Often referred as Government to Citizen (G2C) egovernment services, many governments around the world are developing and utilizing ICT technologies to provide information and services to their citizens. In Saudi Arabia (KSA) egovernment projects have been identified as one of the top government priority areas. However, the adoption of egovernment is facing many challenges and barriers including technological, cultural, organizational which must be considered and treated carefully. This paper explores the key factors of user adoption of e-government services through empirical evidence gathered by survey of 460 Saudi citizens including IT department employees from different public sectors. Based on the analysis of data collected the researchers were able to identify some of the important barriers and challenges from these different perspectives. As a result, this study has generated a list of possible recommendations for the public sector and policymakers to move towards successful adoption of e-government services in Saudi Arabia.
\end{abstract}

Keywords-Challenges; E-government services; adoption; Saudi Arabia; Citizens perspective; IT employees.

\section{INTRODUCTION}

E-government represents a fundamental change in the whole public sector structure, values, culture and the ways of conducting business by utilizing the potential of ICT as a tool in the government agency. The Organization for Economic Cooperation and Development (OECD) [1] defines e-government as "the use of information and communication technologies, and particularly the Internet, as a tool to achieve better government". E-government offers services to those within its authority to transact electronically with the government. These services differ according to users' needs, and this diversity has given rise to the development of different types of egovernment. According to Carter \& Belanger [2] the relationship of government with recipients of its electronic services can be characterized as: Government to Citizen (G2C), Government to Business (G2B); Government to Employees (G2E); or, Government to Government (G2G).

However, many governments are still in the early stages of implementation and adoption of e-government services. Kingdom of Saudi Arabia (KSA), the biggest country in the Middle East, is in process for a transition to e-government. Today, most of the Saudi government ministries, currently 22, have their own web sites. According to Al Nuaim's study [3] which evaluates the Saudi ministries web sites, it was found that $8(41 \%)$ of 21 ministries did not implement the main features of an e-government web site. In addition, 10 ministries (45.4\%) were completely or partially in the first stage (web presence); 3 ministries (13.6\%) were in the second stage (oneway interaction); and 6 ministries had no online service at all. This paper reports on research that seeks to answer the question: "What are the challenges and barriers that affect the adoption of e-government services in Saudi Arabia from citizen and government perspectives?" The findings of this study verified some systemic barriers [10] and the extent that are likely to influence the adoption of e-government services. Systemic barriers include: IT infrastructural weakness in government sector, lack of public knowledge about egovernment, lack of systems to provide security and privacy of information, and lack of qualified IT and government service expert personnel. Finally, it presents a number of critical strategic priorities for the attention of any e-government project implementation in KSA.

\section{RESEARCH Methodology}

In this study a quantitative research method using questionnaires was used to conduct an interpretive study with two sample populations from government IT department employees and members of the general public. Questionnaires are a widely used data collection instrument for recording participant responses to research related questions presented in a predetermined order [4]. Rigorous questionnaire design was undertaken to provide the research with reliable measures that have been validated for this application [5], [6], [7]; also ensuring participants can understand the questions and answer accurately with the most appropriate responses. The questionnaire was used to determine the strength of general citizens' perceptions of obstacles and challenges facing the adoption and diffusion of the e-government services in Saudi Arabia. Also, the same challenges were investigated from IT services providers' perspectives. IT employees in this study represent an element of the government sector and it is very important to explore their expert views and opinions about this issue.

At the beginning of the questionnaire the researcher explained the purpose of the survey and directions for filling out the questionnaire. The questionnaires were distributed to a range of Saudi citizens in public locations such as: shopping centers, internet café and other such locations. For the second sample made up of IT employees such as programmers, software engineers and web designers, participants were approached for participation at their work locations. 
The first section of the questionnaire was designed to capture demographic information such as age, occupation, work experience, and educational background. The second section was designed to obtain information on their capabilities using computers and Internet services. The last section contained eleven previously determined barriers [10] to be identified by respondents as either not a barrier (0) or important barrier (1) or very important barrier (2) as shown in Table 1.

It was included to gain better understanding of challenges and obstacles that prevent or influence e-government services acceptance and use in KSA. Sample populations for this study comprises of two group Saudi citizens and IT employees. 400 respondents were ordinary Saudi citizens while 60 were employees from ten (10) governmental public sectors in KSA. Data were then analyzed using SPSS software where selected variables were subjected to exploratory, descriptive and inferential statistical analysis.

\section{DAta ANAlysis AND Discussion}

The following sections highlight the main findings and provide indications as to how the research question might be answered based on the survey results. The first section presents an overview of the results of the online survey questionnaire then the following two sections illustrate the implications for the research question in more detail.

\section{A. Demographic information}

Table1 and Table 2, following, provide a general overview of the Saudi citizens group and IT employees group in terms of the demographic information, such as gender, age, education level, computer knowledge and internet knowledge. The general population sample might be characterized as being between 21 and 40 years old, mostly degree educated, self identified as having moderate computer knowledge and moderate to good Internet knowledge. By comparison, the major differences in the IT employee group were self identification as having mostly very good computer and Internet knowledge.

\section{B. Interpretation of research Question: Barriers and \\ challenges to E-Government services adoption}

There are many organizational, technical, social and financial barriers that are facing e-government services adoption and diffusion in KSA. Berge, Muilenburg \& Haneghan [8] emphasized that the diffusion of technology into society and citizens is not without obstacles and barriers. However, the government sectors face challenges from Saudi citizens, who expect higher levels of service than from the private sector [9]. The researchers identified eleven barriers to e-government services adoption based empirical research [10] and verified by literature review.

Consequently, participants were asked to evaluate their perceptions of the levels of importance of each barrier by selecting one of the following ( 0 : not a barrier, 1: important barrier, 2: very important barrier).

The barriers that might provide challenges to e-government service adoption are listed in Table 3 and explained in the following sections based on the survey questionnaire groups (Saudi citizens and IT employees).

TABLE I. DEMOGRAPHIC INFORMATION OF SAUDI CITIZENS

\begin{tabular}{|c|c|c|c|}
\hline \multicolumn{2}{|c|}{ Variable } & Frequency & Percent \\
\hline \multirow{2}{*}{ Gender } & Male & 295 & $62.7 \%$ \\
\hline & Female & 105 & $37.3 \%$ \\
\hline \multirow{5}{*}{ Age } & Less than 20 & 85 & $0.6 \%$ \\
\hline & 21-30 & 125 & $48.3 \%$ \\
\hline & 31-40 & 162 & $46.5 \%$ \\
\hline & 41-50 & 19 & $3.5 \%$ \\
\hline & More than 50 & 9 & $1.1 \%$ \\
\hline \multirow{4}{*}{ Education } & H.Shool & 14 & $0.5 \%$ \\
\hline & Diploma & 122 & $22.0 \%$ \\
\hline & Bachelor & 260 & $69.3 \%$ \\
\hline & Higher education & 6 & $8.2 \%$ \\
\hline \multirow{4}{*}{$\begin{array}{c}\text { Computer } \\
\text { knowledge }\end{array}$} & Poor & 13 & $3.5 \%$ \\
\hline & Moderate & 154 & $55.7 \%$ \\
\hline & Good & 225 & $39.7 \%$ \\
\hline & Very good & 8 & $1.0 \%$ \\
\hline \multirow{4}{*}{$\begin{array}{c}\text { Internet } \\
\text { knowledge }\end{array}$} & Poor & 29 & $3.5 \%$ \\
\hline & Moderate & 108 & $49.9 \%$ \\
\hline & Good & 251 & $45.1 \%$ \\
\hline & Very good & 12 & $1.5 \%$ \\
\hline
\end{tabular}

TABLE II. DEMOGRAPHIC INFORMATION OF IT STAFF

\begin{tabular}{|c|l|r|r|}
\hline \multicolumn{2}{|c|}{ Variable } & Frequency & \multicolumn{1}{c|}{ Percent } \\
\hline \multirow{2}{*}{ Gender } & Male & 60 & $100 \%$ \\
\hline \multirow{2}{*}{ Age } & $21-30$ & 25 & $41.7 \%$ \\
\cline { 2 - 4 } & $31-40$ & 35 & $58.3 \%$ \\
\hline \multirow{2}{*}{ Education } & Diploma & 20 & $33.3 \%$ \\
\cline { 2 - 4 } & Bachelor & 40 & $66.7 \%$ \\
\hline \multirow{2}{*}{$\begin{array}{c}\text { Computer } \\
\text { knowledge }\end{array}$} & Good & 13 & $21.7 \%$ \\
\cline { 2 - 4 } $\begin{array}{c}\text { Internet } \\
\text { knowledge }\end{array}$ & Very good & 47 & $78.3 \%$ \\
\cline { 2 - 4 } & Good & 9 & $15.0 \%$ \\
\hline
\end{tabular}


TABLE IV. BARRIERS OF E-GOVERNMENT SERVICES ADOPTION

\begin{tabular}{|c|c|c|c|c|}
\hline No & Barriers & $\begin{array}{c}\text { Not a } \\
\text { barrier }\end{array}$ & $\begin{array}{l}\text { Important } \\
\text { barrier }\end{array}$ & $\begin{array}{l}\text { Very } \\
\text { important } \\
\text { barrier }\end{array}$ \\
\hline 1 & $\begin{array}{l}\text { IT Infrastructural weakness of } \\
\text { government public sectors }\end{array}$ & 0 & 1 & 2 \\
\hline 2 & $\begin{array}{l}\text { Lack of knowledge and ability to use } \\
\begin{array}{l}\text { computers and technology } \\
\text { efficiently }\end{array}\end{array}$ & 0 & 1 & 2 \\
\hline 3 & $\begin{array}{l}\text { Lack of knowledge about the e } \\
\text { government services }\end{array}$ & 0 & 1 & 2 \\
\hline 4 & $\begin{array}{l}\text { Lack of security and privacy of } \\
\text { information in } \\
\text { websites }\end{array}$ & 0 & 1 & 2 \\
\hline 5 & $\begin{array}{l}\text { Lack of users' trust and confidence } \\
\text { to use e-government services }\end{array}$ & 0 & 1 & 2 \\
\hline 6 & $\begin{array}{l}\text { Lack of policy and regulation for e- } \\
\text { usage in KSA }\end{array}$ & 0 & 1 & 2 \\
\hline 7 & $\begin{array}{lcc}\begin{array}{l}\text { Lack of partnership } \\
\text { between } \\
\text { governmental }\end{array} & \begin{array}{c}\text { and } \\
\text { the }\end{array} \\
\end{array}$ & 0 & 1 & 2 \\
\hline 8 & $\begin{array}{l}\text { Lack of technical support from } \\
\text { government's websites support } \\
\text { team }\end{array}$ & 0 & 1 & 2 \\
\hline 9 & $\begin{array}{l}\text { Governmental employees resistance } \\
\text { to change to e-ways }\end{array}$ & 0 & 1 & 2 \\
\hline 10 & $\begin{array}{l}\text { The shortage of financial resources } \\
\text { of government sectors }\end{array}$ & 0 & 1 & 2 \\
\hline 11 & $\begin{array}{l}\text { The availability and reliability of } \\
\text { internet connection }\end{array}$ & 0 & 1 & 2 \\
\hline
\end{tabular}

1) Perception of citizens regarding barriers to $e$ government services

As shown in Table 4 all eleven barriers were selected as either an important or very important barrier and no one of them was selected as not a barrier. In this way the barriers identified both through empirical qualitative investigation [10] and literature review are validated for this sample population.

\section{a) Barriers perceived as being "important"}

Inspecting the top three barriers that citizens perceived as being "important" it can be seen that the IT Infrastructural weakness of government public sectors was popular at $(53.5 \%)$. Moon [11] confirmed that the lack of technical, personnel, and financial capacities are seen as significant obstacles to the development of e-government services in many countries. Moreover, several researchers have mentioned the importance of ICT infrastructure as one of the main barriers in Saudi Arabia [12-15]. Lack of security and privacy of information in government's websites come as the second barrier also with a popularity of $(53.5 \%)$. West [16] emphasized that e-government will not grow without a sense of privacy and security among citizens regarding their online services and information and services providers need to take care of these issues more seriously. The third barrier is about lack of knowledge and ability to use computers and technology efficiently with a popularity of $(51.2 \%)$. This is confirmed as an important barrier that is relevant to Saudi Arabia [17].

\section{b) Barriers perceived as being "very important"}

From the "very important" angle it is clear that lack of technical support from government's websites support team got the highest percentage at $(67.5 \%)$ followed by the availability and reliability of Internet connection with (67.0\%). Al-shehry [19] highlighted the importance of ensuring positive user experiences in building trust in e-government systems. High quality Internet services will provide system performance to create excellent user experiences. Importantly poor user experiences present risks of citizen rejection of e-government services which may prove difficult to recover [19]. The next most popular barrier in the "very important" category was lack of knowledge about the e-government services at (66.5\%). This indicates that a program of promotion is likely to be a significant factor for successful of e- government systems. For any new technology there are many steps to convince and encourage people to accept it and then use it. Research into technology adoption indicates that potential users must perceive that it is useful [28], that it is easy to use [29], and that it provides some relative advantage over the current way of doing things [30]. For citizens to develop these perceptions before extensive experience is gained, programs of promotion and advertising can be key tools to accomplish this task.

TABLE V. ANALYSIS OF E-GOVERNMENT SERVICES OBSTACLES FROM CITIZEN'S PERSPECTIVE

\begin{tabular}{|c|c|c|c|c|c|}
\hline \multirow[t]{2}{*}{ No } & \multirow[t]{2}{*}{ Barriers } & \multicolumn{2}{|c|}{ Important barrier } & \multicolumn{2}{|l|}{$\begin{array}{l}\text { Very } \\
\text { barrier }\end{array}$} \\
\hline & & Frequency & Percent & Frequency & Percent \\
\hline 1 & $\begin{array}{l}\text { IT Infrastructural } \\
\text { weakness of government } \\
\text { public sectors }\end{array}$ & 214 & $53.5 \%$ & 186 & $46.5 \%$ \\
\hline 2 & $\begin{array}{l}\text { Lack of knowledge and } \\
\text { ability to use computers } \\
\text { and technology } \\
\text { efficiently }\end{array}$ & 205 & $51.2 \%$ & 195 & $48.8 \%$ \\
\hline 3 & $\begin{array}{l}\text { Lack of knowled ge about } \\
\text { the e-government } \\
\text { services }\end{array}$ & 274 & $33.5 \%$ & 544 & $66.5 \%$ \\
\hline 4 & $\begin{array}{l}\text { Lack of security and } \\
\text { privacy of information in } \\
\text { government's websites }\end{array}$ & 214 & $53.5 \%$ & 186 & $46.5 \%$ \\
\hline 5 & $\begin{array}{l}\text { Lack of users' trust and } \\
\text { confidence to use e- } \\
\text { government services }\end{array}$ & 197 & $49.3 \%$ & 203 & $50.7 \%$ \\
\hline 6 & $\begin{array}{l}\text { Lack of policy and } \\
\text { regulation for e-usage in } \\
\text { KSA }\end{array}$ & 198 & $49.5 \%$ & 202 & $50.5 \%$ \\
\hline 7 & $\begin{array}{l}\text { Lack of partnership and } \\
\text { collaboration between } \\
\text { the governmental } \\
\text { sectors }\end{array}$ & 166 & $41.5 \%$ & 234 & $58.5 \%$ \\
\hline 8 & $\begin{array}{l}\text { Lack of technical support } \\
\text { from government's } \\
\text { websites support team }\end{array}$ & 130 & $32.5 \%$ & 270 & $67.5 \%$ \\
\hline 9 & $\begin{array}{l}\text { Governmental } \\
\text { employees resistance to } \\
\text { change to e-ways }\end{array}$ & 170 & $42.5 \%$ & 230 & $57.5 \%$ \\
\hline 10 & $\begin{array}{l}\text { The shortage of financial } \\
\text { resources of government } \\
\text { sectors }\end{array}$ & 198 & $49.5 \%$ & 202 & $50.5 \%$ \\
\hline 11 & $\begin{array}{l}\text { The availability and } \\
\text { reliability of internet } \\
\text { connection }\end{array}$ & 132 & $33.0 \%$ & 268 & $67.0 \%$ \\
\hline
\end{tabular}

2) Perception of IT employees toward obstacles of $e$ government services

Table 5 summarizes the barriers from the analysis of IT employees' perspectives. Again, the three most popularly identified barriers from the two perception levels will be illustrated in the following subsections. 


\section{a) Barriers perceived as being "important"}

Of the barriers that IT employees perceived as "important" it is clear that lack of knowledge and ability to use computers and technology efficiently ranked most highly at (68.3\%). The ability of citizens to effectively use computers and the Internet is a critical success factor in e-government projects, and the lack of such skills may lead to marginalization or even social exclusion [20]. Lack of security and privacy of information in government's websites presented as the second most popular barrier at this level of importance at (65.0\%). Ndou [21] considered privacy and confidentiality as critical obstacles toward the realization of e-government in developing countries. It was revealed that citizens studied were deeply concerned with the privacy of their information and confidentiality of the personal data they are providing as part of obtaining government services. Thus, it was pointed out that privacy and confidentiality are high priorities when establishing and maintaining web sites in order to ensure the secure collection of data. On the other hand governments should provide a secure authenticated access to their online services in order to maintain citizen trust in use of e-government services. Practically, media campaigns and promotion through awareness seminars and brochures about safe Internet use and security principles is an important supporting strategy in citizen acceptance of any e-government system. E-government systems are revolutionary in many developing countries around the world and support its effective use it requires appropriate policies and regulatory framework. Such laws and regulation should be "e-aware" to cover all e-applications such as epayments, e-mail usage, copyright rules, e-crimes, e-business, e-commerce and others [22]. In the KSA case, the Saudi government has issued many government regulations and laws such as e-transaction law, information criminal law, shift to electronic methods decision and many other laws. These laws and regulations are playing an important function in promoting effective communication between citizens, business and government to accelerate the adoption of e-government service on all levels. However, the existence of these laws and regulations is but one step in e-government adoption process and needs information about them to be published in the community domain to facilitate and provide confidence in their use.

\section{b) Barriers perceived as being "very important"}

From the barriers that IT employees viewed as "very important" Table 5 reveals that the lack of technical support from government's websites support teams got the highest percentage at $(93.3 \%)$. Thus a fast and accurate technical support service is an essential part of an effective and efficient e-government system. Citizens may understandably be easily deterred by technical failures, so it is very important to have a professional team to detect and respond to technical issues and to help users as soon as possible. Citizens require high-quality technical support, in order to learn how to use the e-services and become familiar with them. Hoffman [23] defined technical support as "knowledge people assisting the users of computer hardware and software products', which can include help desks, information centre support, online support, telephone response systems, e-mail response systems and other facilities. Technical support is one of the significant factors in the acceptance and use of technology [24, 25], and accordingly in the adoption of e-applications such as egovernment services. The second most popularly perceived "very important" barrier was lack of knowledge about egovernment services at $(81.7 \%)$. As raised earlier, effective promotion is likely to be one of the most significant factors influencing successful citizen adoption of e-government systems [26]. For any new technology there are many steps to convince and encourage people to adopt and use it so promotion and advertising are tools central to accomplishing this task. The survey results indicate that the lack of programs to promote the e-government services benefits and advantages may be a significant barrier to the adoption of e-government in Saudi society. The third most popular "very important" barrier was IT infrastructural weakness in government public sectors at $(80.0 \%)$. The ICT infrastructure is an essential part of successful e-government implementation and diffusion [17]. It enables government agencies to cooperate, interact and share work in an effective and professional fashion. Development of ICT infrastructure, both in government and private domains, needs to be sensitively handled in the Saudi context and accompanied by an effective, staged roll-out strategy [27].

TABLE VI. ANALYSIS OF E-GOVERNMENT SERVICES OBSTACLES FROM IT EMPLOYEE'S PERSPECTIVE

\begin{tabular}{|c|c|c|c|c|c|}
\hline \multirow[t]{2}{*}{ No } & \multirow[t]{2}{*}{ Barriers } & \multicolumn{2}{|c|}{ Important barrier } & \multicolumn{2}{|c|}{$\begin{array}{l}\text { Very important } \\
\text { barrier }\end{array}$} \\
\hline & & Frequency & Percent & Frequency & Percent \\
\hline 1 & $\begin{array}{l}\text { IT Infrastructural } \\
\text { weakness of government } \\
\text { public sectors }\end{array}$ & 12 & $20.0 \%$ & 48 & $80.0 \%$ \\
\hline 2 & $\begin{array}{l}\text { Lack of knowledge and } \\
\text { ability to use computers } \\
\text { and technology efficiently }\end{array}$ & 41 & $68.3 \%$ & 19 & $31.7 \%$ \\
\hline 3 & $\begin{array}{l}\text { Lack of knowledge about } \\
\text { the e-government services }\end{array}$ & 11 & $18.3 \%$ & 49 & $81.7 \%$ \\
\hline 4 & $\begin{array}{l}\text { Lack of security and } \\
\text { privacy of information in } \\
\text { government's websites }\end{array}$ & 39 & $65.0 \%$ & 21 & $35.0 \%$ \\
\hline 5 & $\begin{array}{l}\text { Lack of users' trust and } \\
\text { confidence to use e- } \\
\text { government services }\end{array}$ & 26 & $43.3 \%$ & 34 & $56.7 \%$ \\
\hline 6 & $\begin{array}{l}\text { Lack of policy and } \\
\text { regulation for e-usage in } \\
\text { KSA }\end{array}$ & 38 & $63.3 \%$ & 22 & $36.7 \%$ \\
\hline 7 & $\begin{array}{l}\text { Lack of partnership and } \\
\text { collaboration between the } \\
\text { governmental sectors }\end{array}$ & 36 & $60.0 \%$ & 24 & $40.0 \%$ \\
\hline 8 & $\begin{array}{l}\text { Lack of technical support } \\
\text { from government's } \\
\text { websites support team }\end{array}$ & 4 & $6.7 \%$ & 56 & $93.3 \%$ \\
\hline 9 & $\begin{array}{l}\text { Governmental employees } \\
\text { resistance to change to e- } \\
\text { ways }\end{array}$ & 33 & $55.0 \%$ & 27 & $45.0 \%$ \\
\hline 10 & $\begin{array}{l}\text { The shortage of financial } \\
\text { resources of government } \\
\text { sectors }\end{array}$ & 18 & $30.0 \%$ & 42 & $70.0 \%$ \\
\hline 11 & $\begin{array}{l}\text { The availability and } \\
\text { reliability of internet } \\
\text { connection }\end{array}$ & 15 & $25.0 \%$ & 45 & $75.0 \%$ \\
\hline
\end{tabular}

\section{3) Comparison of perceptions of barriers}

The aim of this section is to compare between the viewpoints of Saudi citizens and IT employees about barriers to adoption of e-government services. It is clear from the 
previous sections that there are many perceived barriers that are common to both. Firstly, both sample populations nominated lack of technical support for government websites as a "very important" barrier and ranked that as the most important barrier in the list. This agreement between both sample populations indicated that it is a critical barrier to be resolved with a high level of priority. Next, both groups agreed that lack of knowledge about the e-government services was considered the second or third most important barrier in the "very important barriers" list. Finally, there was a distinction in the next most popular "very important" barrier to e-government adoption and this reflects the individual perspectives of the sample populations. For the IT employees within the government IT infrastructural weakness was seen as a significant barrier to them being able to provide reliable and effective services. From the perspective of the ordinary citizenry having access to reliable and effective Internet services has impact on their ability to access and make effective use of the available services. Table 6 presents the common barriers and distinct barriers with their relative popularity.

TABLE VII. COMMON AND DISTINCT BARRIERS BETWEEN THE TWO GROUPS

\begin{tabular}{|l|l|l|l|}
\hline \multicolumn{1}{|c|}{ Barrier } & Rank & \multicolumn{2}{c|}{ Percent } \\
\cline { 3 - 4 } & & Citizens & $\begin{array}{c}\text { IT } \\
\text { employees }\end{array}$ \\
\hline $\begin{array}{l}\text { Lack of technical support from } \\
\text { government's websites support }\end{array}$ & 1 & $67.7 \%$ & $93.3 \%$ \\
\hline $\begin{array}{l}\text { Lack of knowledge about the e-government } \\
\text { services }\end{array}$ & 2 & $66.5 \%$ & $81.7 \%$ \\
\hline $\begin{array}{l}\text { The availability and reliability of internet } \\
\text { connection }\end{array}$ & 3 & $67.2 \%$ & $75.0 \%$ \\
\hline $\begin{array}{l}\text { IT Infrastructural weakness of government } \\
\text { public sectors }\end{array}$ & 3 & $46.5 \%$ & $80.0 \%$ \\
\hline
\end{tabular}

\section{IMPLICATIONS FROM RESEARCH}

Based on the research outcomes, the highest priority strategies to be implemented to help successful adoption of egovernment services in Saudi Arabia are:

- Instantiation of reliable and responsive technical support systems that cover all Saudi government organizations and agencies. Results indicate that technical support is the foundation stone of a successful adoption program and should be integral to e-services rollout. Any weakness in technical support systems may present a barrier to all e-government implementation stages.

- Instantiation of comprehensive information and training programs that raise citizen awareness and knowledge of e-government services as they become accessible in each region. An associated advertising campaign focusing on each emerging e-government system and service with its benefits and advantages.

- Acceleration of the rollout of high performance network and Internet infrastructure to government agencies and service providers. Acceleration of the rollout of high performance Internet infrastructure starting with the areas of highest population density.
These can then be supported by:

- Development and adoption of a set of standards and processes for the design, development, and maintenance of all government websites. Instantiation of government Web developer training programs to ensure appropriately skilled professionals needed to build and maintain websites that provide a high level of transaction security and ease of use for all eservices.

- Instantiation of interagency agreements that require and promote high levels of collaboration, cooperation, and service consistency between all government agencies and with the ongoing Yesser national egovernment development project [13].

- Instantiation of standards and protocols to ensure and enforce highest levels of information security and privacy across all e-government agencies and services. Instantiation of standardized trusted payment systems and gateways which are highly secure, highly accessible, and simple to use for all online transactions.

\section{CONCLUSION}

Citizen's adoption of e-government services is an important goal for many governmental service providers, however the success of this adoption process is not easy and requires a thorough understanding of the needs of citizens and system requirements. This paper focuses on the barriers of egovernment services adoption in Saudi Arabia.

The result of this work based on the response of Saudi citizens and IT employees in public sectors to the research question. Based on the data collected through a questionnaire survey the researchers identified and uncovered many important factors which affect directly the adoption process. It is clear that there are many important factors which common between the two groups and that need to be addressed in quick and professional manner. As result of this study, a brief set of recommendations has been made in order to help the public sectors and government originations to improve the egovernment services outcome and to achieve the aspirations of Saudi citizens and their satisfaction with electronic services.

\section{REFERENCES}

[1] OECD, OECD E-Government Flagship Report "The E-Government Imperative," Public Management Committee, Paris: OECD, 2003

[2] Carter, L., \& Belanger, F. (2005). The utilization of e-government services: citizen trust, innovation and acceptance factors. Information Systems Journal, 15(1), 5-25.

[3] Al-Nuaim, H. (2011) An Evaluation Framework for Saudi EGovernment, Journal of e-Government Studies and Best Practices, Vol. 2011 (2011)

[4] Neuman, W. (2006) Social research methods: qualitative and quantitative approaches, 6th edn, Allyn and Bacon, Boston, MA, USA.

[5] Al- Shareef, K. (2003). The challenges that face e-government in Saudi Arabia. Work report, King Saud University, Riyadh, Kingdom of Saudi Arabia.

[6] Al-Smmary, S., (2005). E-readiness in Saudi Arabia. Work report, King Fahd University of Petroleum and Minerals, Damamm, Kingdom of Saudi Arabia. 
[7] Al-Solbi, H. \& Al-Harbi,S. (2008). An exploratory study of factors determining e-government success in Saudi Arabia. Communications of the IBIMA, Volume 4, 2008

[8] Berge, Z. L., Muilenburg, L. Y., \& Haneghan, J. V. (2002). Barriers to distance education and training. The Quarterly Review of Distance Education, 3(4), 409-418.

[9] Chavez, Regina. (2003). the utilization of the mazmanian and sabatier model as a tool for implementation of e-government for Fresno county, California. Doctoral Dissertation. California State University.

[10] Alshehri, M. \& Drew, S. (2010). Challenges of e-Government Services Adoption from an e-Ready Citizen Perspective. World Academy of Science, Engineering and Technology, 66, 1053-1059.

[11] Moon, M. (2002).The evolution of e-government among municipalities: rhetoric or reality. Public Administration Review 62 (4): 424-33.

[12] Al-Ghaith, W.A., Sanzogni, L. and Sandhu, K. (2010), "Factors influencing the adoption and usage of online services in Saudi Arabia", Electronic Journal on Information Systems in Developing Countries, Vol. 40 No. 1, pp. 1-32,

[13] Al-shehry, A., Rogerson, S., Fairweather, N. \& Prior, M,. (2006). Egovernment adoption: an empirical study. The Information Communication \& Society (ICS) 10th Anniversary Symposium, York, 20-22 September 2006.

[14] Al-Sobhi, F., Weerakkody, V. \& Kamal, M. M. 2010. „An exploratory study on the role of intermediaries in delivering public services in Madinah City: Case of Saudi Arabia ${ }^{\text {ee }}$ Transforming Government: People, Process and Policy, 4(1):14-36.

[15] A. Al-Solbi and S. Al-Harbi, (2008) An exploratory study of factors determining e-Government success in Saudi Arabia, Computer Centre, Air Academy, Riyadh, Saudi Arabia.

[16] West, D.M. (2001). State and Federal E-government in United States, Available at:http://www.insidepolitics.org/egovt01us.html. Accessed on 25/08/2011

[17] Al-Zumaia, Abdulrahman. S. (2001). Attitudes and Perceptions Regarding Internet-Based Electronic Data Interchange in Public Organization in Saudi Arabia. Doctoral Dissertation. University of Northern Iowa

[18] Feng. L. (2003). Implementing E-government Strategy is Scotland: Current Situation and Emerging Issues. Journal of Electronic Commerce in Organizations 1(2), 44-65

[19] Al-shehry, A., (2008). Transformation towards E-government in The Kingdom of Saudi Arabia: Technological and Organisational Perspectives . Doctoral Dissertation De Montfort University, UK.

[20] United Nations Division for Public Economics and Public Administration, (2001). Benchmarking Egovernment: A Global
Perspective - Assessing the Progress of the UN Member States., from http://pti.nw.dc.us/links/docs/ASPA_UN_egov_survey1.pdf Accessed on $19 / 12 / 2011$

[21] Ndou , V. (2004). E-government for developing countries: opportunities and challenges. The Electronic Journal on Information Systems in Developing Countries 18, 1, 1-24

[22] Ralph, W. (1991). Help! The art of computer technical support. California: Peachpit Press.

[23] Hofmann, D. W. (2002). Internet-based distance learning in higher education. Tech Directions, 62(1), 28-32.

[24] Williams, P. (2002). The learning Web: the development, implementation and evaluation of Internet-based undergraduate materials for the teaching of key skills. Active Learning in Higher Education, 3(1), 40-53.

[25] Geetika, P. (2007). Strategic Marketing of E-Government for Technology Adoption Facilitation Available online at: www.csisigegov.org/critical_pdf/6_51-60.pdf . Accessed on 22/05/2010.

[26] Jaegar, P. and Thompson, K. (2003), E-Government around the world: Lessons, Challenges and Future Directions, Government Information Quarterly 20, 329-394

[27] Dada, D. (2006) The Failure of E-Government in Developing Countries, retrieved 2006, available at http://www.lse.ac.uk/collections/informationSystems/iSChannel/Dada_2 006b.pdf. Accessed on 20/11/2011

[28] Davis, F. (1989) Perceived Usefulness, Perceived Ease of Use, and User Acceptance of Information Technology, MIS Quarterly, 13(3), 319-340.

[29] Venkatesh, V. (2000) Determinants of Perceived Ease of Use: Integrating Control, Intrinsic Motivation, and Emotion into the Technology Acceptance Model, Information Systems Research, 11(4), 342-365.

[30] Moore, G, C. and Benbasat, I. (1991) Development of an instrument to measure the perceptions of adopting an information technology innovation, Information Systems Research, 2, 192-222.

\section{AUTHORS PROFILE}

Dr Steve Drew is a Senior Lecturer in the School of ICT at Griffith University. He heads a group of researchers looking at different aspects of information systems e-services acceptance and adoption.

Mohammed Alshehri is a Ph.D candidate at ICT School at Griffith University at Australia. He received his MSC in Computer and Communication Engineering from QUT in Brisbane in 2007.

Osama Alfarraj is a Ph.D candidate at ICT School at Griffith University at Australia. He received his MSC in IT from Griffith University in Brisbane in 2008 